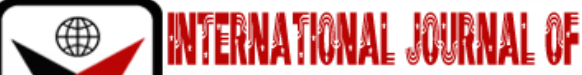

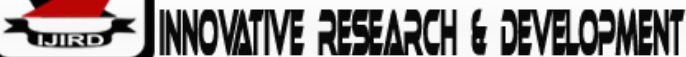

ISSN 2278-0211 (Online)

\section{The Role of Tourism on a Geosites's Space Development Case: Watu Payung-Turunan Geoforest Yogyakarta, Indonesia}

\begin{tabular}{c} 
Primantoro Nur Vitrianto \\
Doctoral Student, Department of Architecture and Planning, \\
Gadjah Mada University, Indonesia \\
Wiendu Nuryanti \\
Professor, Lecturer, Department of Architecture and Planning, \\
Gadjah Mada University, Indonesia \\
Dwita Hadi Rahmi \\
Lecturer, Department of Architecture and Planning, \\
Gadjah Mada University, Indonesia \\
\hline
\end{tabular}

\section{Abstract:}

Geoforest Watu Payung-Turunan is a semi-production conservation forest in forest ecosystems in karst areas that are part of the UNESCO Global Geopark Network. However, this valuable affiliation has not brought any significant effect on geoforest's development. Meanwhile, the community independently provides tourism facilities by utilizing and changing space elements, particularly the semi-fixed elements. Therefore, semi-fixed elements are the most affected and affecting tourism development.

The research aims to comprehend the influence of tourism on space elements of the geosite. Researchers used a qualitative descriptive method to explore tourism development and its effects on space elements development through interviews, field observations, and literature reviews. This research proved that the semi-fixed elements are the most changing elements and determine the tourism space structure. The dynamics of tourism activities as nonpermanent elements significantly affect the development of semi-fixed elements on geoforest.

Keywords: Influence of tourism on space elements, Geoparks, Geotourism, Ecotourism, Watu Payung-Turunan Forest, Yogyakarta

\section{Introduction}

Geopark-based tourism or geotourism is defined as tourism that focused on geological and landscape attractions for travellers. Geotourism has a close connection with earth tourism, culture tourism, and ecotourism. Geotourism aims to preserve geoheritage resources, empower communities, promote geological heritage, and establish cross-sectoral cooperation. The geological attraction of a geopark continuously developed to empowered local communities and regions. Geopark or earth park is a new concept in tourism developed by the Indonesian Ministry of Tourism after being introduced by UNESCO in 2000. Theoretically, geopark is expected to preserve nature and improve public living standards.

WatuPayung-Turunan Geoforest is a production forest that was initially prepared as a dry limestone land. The forest is converted into a protected forest for the benefit of conservation and tourism. The development approaches implemented in the geopark region tend to be focusing on the conservation aspect and neglecting the economic prosperity aspect for the community. Keever and Zouros (2005) explain that geopark is a unified territory that provides protection and sustainable use of potential geological heritage and encourages the community's economic prosperity. The dynamical development of a geopark also affects the development of the existing cultural landscape. Cultural landscape or Saujana itself is interpreted as a reflection of the relationship between natural heritage and cultural heritage in broad unity of space and time, and constitute complex phenomena with tangible and intangible identity. (Rahmi et al., 2012). The dynamics of geopark development cannot be separated from space changes, which are influenced by facilities' development within the geosite.

Ideally, geopark development serves to maintain geological uniqueness. But on the other hand, geopark development must also be able to increase the regional economy and improve the welfare of the community. Geopark development is carried out in various ways, one of which is the development of the area around the geopark (buffer) for the benefit of geopark visitors. Various motivations for visits such as education, research, and tourism take place within the geopark. The various interests of these visitors will demand changes in land use in accordance with these motives. The problem is whether tourism development promotes the development of facilities, which in turn affected the space 
rather than determining the geopark itself. Is the facility factor as a part of the geopark element the most vulnerable factor to tourism development? This question requires an in-depth analysis of how tourism development affects space changes in a geosite. In this study, the author used the space-forming element concept by Rapoport (1997) to investigate the problem and answers the question. Rapoport divides the space-forming elements into three groups based on their physical composition, namely fixed elements, semi-fixed elements, and non-permanent elements.

Previous research related to spatial changes has been carried out, but those related to the constituent elements of space are still limited. Putri (2019) examines collaboration among stakeholders in the context of developing tourism destinations. Other research on geoparks focuses more on the development and function of geoparks, or approaches in its development such as geotourism. Kikuchi et al. (2011) examines the relationship between geotourism and geopark concepts, the principle of sustainability and their contribution to regional development. Yuliawati, Pribadi, and Hadian (2016) observed geotourism as part of sustainable development

\section{Literature Review}

\subsection{Tourism}

Tourism is an activity that aims to get pleasure and satisfaction in enjoying the beauty of a tourist attraction. Indonesian Constitution No. 10, the year 2009, defined tourism as the whole activities related to tourism that tends to be multidimensional and multidisciplinary. Soedarso, Nurif, and Windiani (2014) explain that tourism as a travel activity from an original living place to various places to make tourism visit, not for working or earning a living, is carried out by an individual or a family or group of people. Meanwhile, according to Gunn and Larsen (1988), tourism is any form of travel to temporarily stay in a particular area or specific region to have sightseeing only, visiting friends or relations, having a vacation, and having business activities. Goeldner and Ritchie (2009) define tourism as an industry that consists of 4 (four) main aspects, namely 1) tourists, 2) a service business providing tourist needs (goods and services), 3) local government (the government of the host community area), and 4) the social community as the host.

Meanwhile, according to Macintosh and Goldner, in Soeroso (2017), tourism can be interpreted as "...the sum of the phenomena relationship arising from the interaction of tourists, business suppliers, host governments and host communities in the process of attracting and hosting these tourists and other visitors". The tourism industry is merely a phenomenon caused by the interaction or contact between its aspects. Another definition is also expressed by McIntosh and Wall (1982) in Gunn (1994), that tourism is a temporary movement of the population to a tourist destination, conduct activities at the tourist destination where the availability of facilities meet up the tourists' needs. Tourism is an action taken by tourists for having vacation out of the daily life for a temporary escape from daily activities, caused by some needs without expecting rewards, getting pleasure, and enjoying various entertainments that can reduce fatigue and travel experiences. (Zakaria and Suprihardjo 2014)

Tourism is a series of travel activities carried out by individual or families, or groups from the original residence to various other places to make tourist visit (temporarily and in due to return to the original location of residence) and not to work or earn a living on the arrival spot, (Soedarso, Nurif, and Windiani 2014). Tourism consists of two essential elements: the journey itself and temporary reside at the destination with some tourist activities. As a concept, tourism destinations have a different understanding; Hall (2000), Davidson and Maitland (1997) explain that tourism destinations are a unity of tourism product factors (attractions, security, and access) and a complete/integrated experience for consumers or tourists (Nadjmi et al. 2016).

The destination is also interpreted as a geographical area, such as a country, island, or city. Leiper (1995) explains that tourism destinations are one's destination in traveling for a while to enjoy and feel the experience of a particular tourist attraction or a specific attraction (Nadjmi et al. 2016). Tourism Destinations can define as the integration of facilities designed to meet the tourists (Cooper et al. 2005). According to Cooper et al. (2005)., the concept of tourist attraction includes 4 (four) principal components, namely attraction, accessibility, amenity, and ancillary. Each component is explained below:

- The attraction is a significant component in attracting tourists. An area can be called as a destination when it has a potential tourist attraction to be developed. The potential is in line with the needs and desires of the traveller. Possible tourist attractions are divided into natural tourist attractions (Natural Resources), cultural tourist attractions, and human-made tourist attractions.

- Amenities or facilities are any kinds of facilities and infrastructure required by tourists while in a tourist destination. The facilities and infrastructure include lodging, restaurants, transportation, and travel agents. Besides, amenities can also develop tourist facilities such as hotels, tourist attractions, marinas, and buildings performances. Means of tourism can be water supply, electric power, garbage disposal bin, airport, port, and telephone. Tourism infrastructure and tourism facilities have a connection in their development.

- Accessibility is everything related to transportation and transportation services issues that support tourism interests, such as airports, ports, highways, buses, etc. Accessibility is also interpreted as ease to move from an area to another area. The availability of accessibility in a tourist area is very influential in tourist visitation to the site.

- Additional services or supporting tourism can be interpreted as a government's service or authority to benefit tourism. Ancillary covers marketing, physical development (management agencies, tourist information, travel agent supporting facilities for tourism, drinking water, electricity, telephone, and others), and the coordination of all kinds of tourism activities.

Tourism activities have been developed at the GunungSewuGeopark and the WatuPayung - Derivation geosite. The 
tourism development model used in WatuPayung - Derivative is geotourism with the principles of green-tourism and sustainability aspects. Abiotic, biotic, cultural components are developed into objects and attractions of tourism, always thinking about environmental sustainability aspects (Geopark Gunungsewu Management 2013).

\subsection{Geopark}

Geopark is an area that has unique geology (outstanding geology), including archaeology, ecology, and cultural uniqueness, while also involving the community to play a role in protecting and enhancing the function of natural heritage (UNESCO 2004). Geopark is a sustainable development concept in an area with a unique geoheritage international importance (Robinson 2015). Geopark is a relatively new concept of development. It focuses on regional, national, and geo-social topics, which can serve as an instrument to coordinate stakeholders to head to common goals, which are sustainable development (Pforr and Megerl (2006) in Newsome (2006).

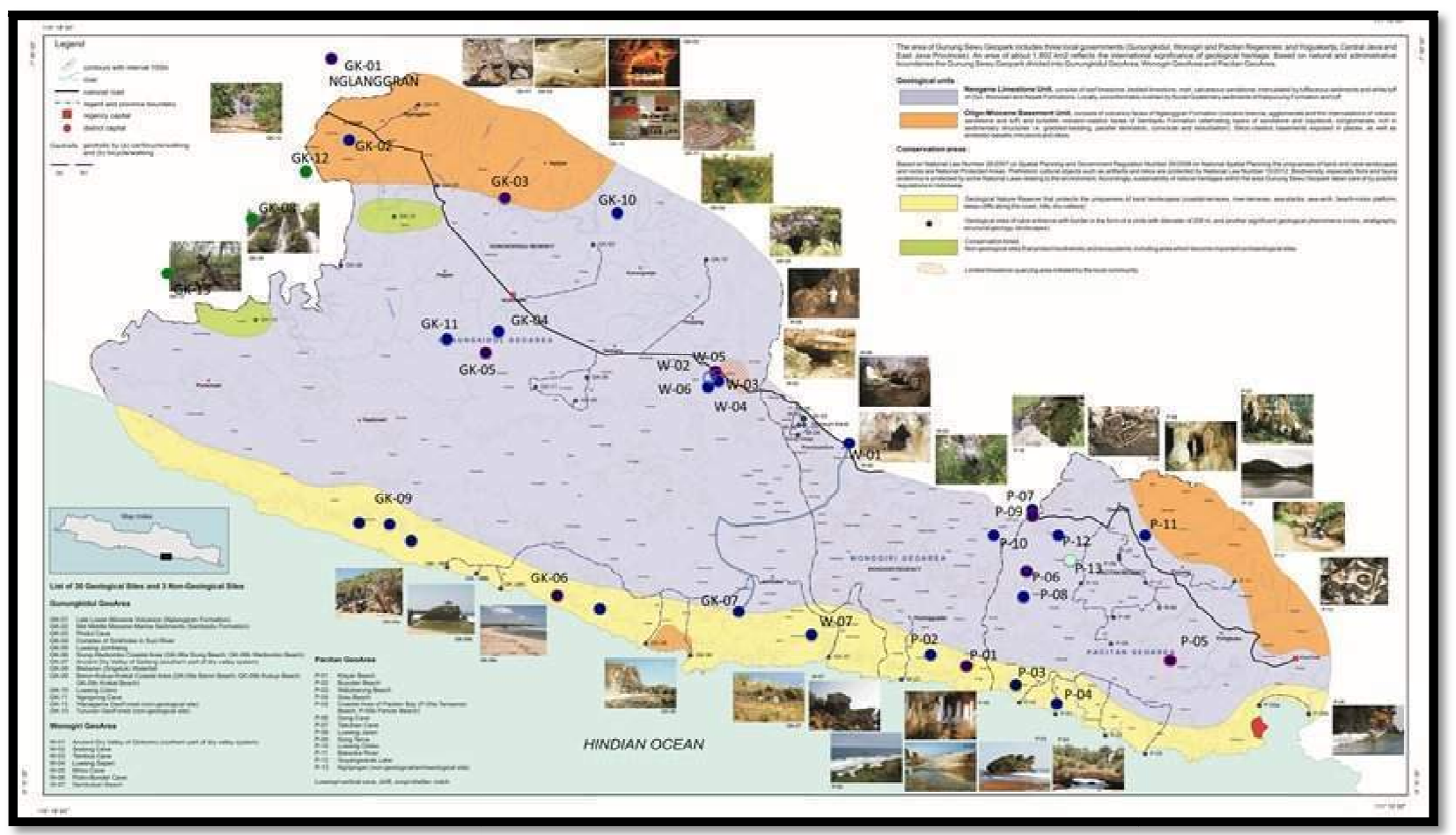

Figure 1: Map of Gunungsewu Geopark, Which Includes Yogyakarta, Central Java and East Java (Inset: Java Island)

Gunungsewu Region (figure.1) has a very diverse earth tourism potential; one of it is developed as the geotourism model in a specific area called geopark. The area is recognized as a national geopark and constitutes part of the Global Geopark Network. According to Amelia (2016), the global geopark network was formed in 2011 under UNESCO's control and initiative to seek and promote the conservation of geological heritage and to encourage development and ongoing research in the community. According to the European Geopark Network (EGN) and Global Geopark Network (GGN), geopark is an area with specific boundaries that allow various activities to develop sustainable development through social, economic, cultural, and environmental aspects.

According to Darsiharjo, Supriatna, and Saputra (2016), geopark is an earth garden included in a conservation area, which has some element of geodiversity (geological diversity), biodiversity (biological diversity), and cultural diversity. Geopark also contains some aspects in the education field as knowledge in geoscience on its uniqueness and the diversity of the earth's heritage and the economic aspect of the society's role in managing the area as geotourism. Keever and Zouros (2005) stated that geotourism and geopark provide a sustainability principle that can positively impact the local economy through the growing number of tourists visit. The tourist visit plays an essentials role in the development of the local economy.

Tourism development in certain areas is able to comprehend by the demand and supply approach (Gunn 1994). This approach is applied by adjusting the development of a tourist area through tourism indicators (Cooper et al. 2005). The tourism indicators involve 4 (four) principal components of tourism, namely: attraction, accessibility, amenities, and ancillary.

The space usage pattern aims to realize social, economic, and cultural development goals according to the potential of natural, human, and artificial resources through the distribution of cultivation and protection activities and their interrelationships (Chamdany 2004 in Haryanti 2008). The space usage in the geopark area is the usage to conserve the natural heritage, develop society, and increase economic growth, as Komoo (2016) stated. 


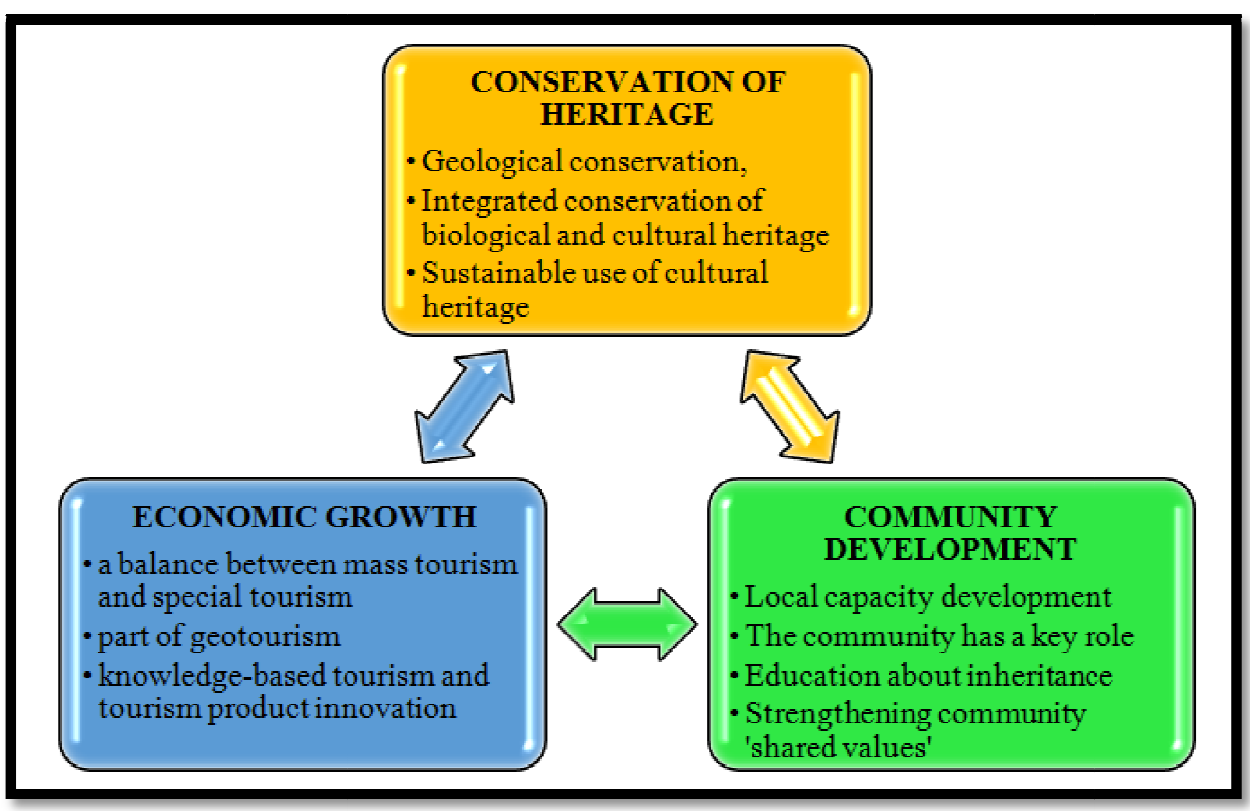

Figure 2: Geopark Development Framework (Komoo 2016)

As stated in the previous paragraph, the three kinds of space usage have their contradiction and expectation, combined in geopark development. An in-depth study of space usage is required to comprehend the space elements, which has an essential role in developing the space function concerning tourism development.

\subsection{Space Element in Geosite}

Space is an unlimited three-dimensional area where the object has a relative position and direction (The Editors of Encyclopedia Britannica 2017). Space change will provide an identity for the area by concerning the changed parts and unchanged parts, in other cases, as delivered by Nuryanti (1996) in her quote about the supporting area element based on the Rapoport model. In tourism development, the spaces exist within an area; consequently, they will continuously change based on the land usage requirements.

Nuryanti (1996) states that there are three elements that constitutes the heritage area, namely: fixed elements, semi-fixed elements, and non-fixed elements. A fixed element is a component that is uneasily changed, rarely or slowly changed, orderly and structured, such as buildings, cities, and ruins. A semi-fixed element is an element that can be moved quickly and easily, like furniture and plants. The non-fixed element is humans that inhabit the area. Furthermore, Rapoport, Altman, and Wohlwill (1980) state that culture and the artificial environment change simultaneously. The changes are divided into three groups; which are:

- The core element, which is an element that changes very slowly and becomes an area's architectural identity.

- The peripheral element, which is the element that easily alters or change and has an insignificant role in the whole change.

- The new element, which is an element adopted by cultural actors and becomes a new part of the area's architecture.

- According to Rapoport (1997), physical setting elements are divided into three types; namely:

- A fixed element, which is a fixed or rarely changes' element. This element can be categorized by sizes, locations, sequences, arrangements, such as roads, buildings, and dividing walls.

- Semi-fixed element, which is an element with quickly and relatively rapid changes, the existence is not permanent, can be changed or eliminated anytime, such as tarpaulin seat.

- Non-fixed element, which is an element related to behavior or human behavior, always impermanent, very dynamic, and generally always different every time it is observed, such as social activities, traveling vendors, vehicle drivers.

Space changes in the geopark can be observed through two kinds of perspectives. Firstly, from the perspective of tourism space and the constituent elements that affects the geosite. The second perspective is space change driven by the interest of geopark in the framework of conservation. According to Nuryanti (1996), the development of each tourism element consists of three groups of elements forming cultural heritage areas, namely fixed elements, semi-fixed elements, and non-permanent elements, which are also elements of physical arrangement.

The Rapoport model approach study was conducted to understand the development and change of space elements in WatuPayung-TurunanGeoforest. According to Rapoport, Altman, and Wohlwill (1980), Rapoport (1997), and (Rapoport 2005), space in the context of the geopark (Gunungsewu) is formed by the elements that are grouped into fixed element, semi-fixed element, and non-fixed element. The fixed element is mountains, valleys, rivers, caves, landscape areas. The semi-fixed element is buildings and neighborhood roads. Non-fixed elements are composed of human activities as an inhabitant in that area, such as street vendors, tourists, and so on.

The Rapoport model mostly focused on micro spaces and urban spaces. In this study, the model shifted to use in protected areas, as described in table 3 below: 


\begin{tabular}{|c|c|c|c|}
\hline $\begin{array}{c}\text { Rapoport } \\
\text { Shifting }\end{array}$ & Fixed Element & Semi-Fixed Element & Non-Fixed Element \\
\hline $\begin{array}{l}\text { Rapoport, } \\
\text { Altman, } \\
\text { and } \\
\text { Wohlwill } \\
\text { (1980) }\end{array}$ & $\begin{array}{l}\text { The core element: } \\
\text { slowly changing and } \\
\text { becomes the } \\
\text { identity of the } \\
\text { architecture owner }\end{array}$ & $\begin{array}{l}\text { The peripheral element: } \\
\text { insignificance and easy to } \\
\text { change }\end{array}$ & $\begin{array}{l}\text { new element adopted by } \\
\text { the owner of culture and } \\
\text { become a new part of the } \\
\text { architecture, such as } \\
\text { social activities, trade, } \\
\text { pedestrians. }\end{array}$ \\
\hline $\begin{array}{l}\text { Rapoport } \\
\text { (1997) }\end{array}$ & $\begin{array}{l}\text { Unchangeable or } \\
\text { rarely changes can } \\
\text { be organized by } \\
\text { sizes, locations, } \\
\text { sequences, and } \\
\text { arrangements. }\end{array}$ & $\begin{array}{l}\text { Quite quickly and easily } \\
\text { changing, not permanent, } \\
\text { and can be changed or } \\
\text { eliminated at any time. }\end{array}$ & $\begin{array}{l}\text { It is related to human } \\
\text { behavior or behavior, } \\
\text { impermanent, and very } \\
\text { dynamic such as social } \\
\text { activities, peddlers, } \\
\text { vehicle drivers. }\end{array}$ \\
\hline $\begin{array}{l}\text { Rapoport } \\
\text { (2005) }\end{array}$ & $\begin{array}{l}\text { Stable and rarely } \\
\text { changes elements. }\end{array}$ & $\begin{array}{l}\text { Include various components } \\
\text { ranging from furniture, } \\
\text { curtains, booths, street } \\
\text { furniture, shop windows, } \\
\text { and another city element. } \\
\text { The importance of these } \\
\text { elements is more than the } \\
\text { constant element in } \\
\text { transmitting meaning in the } \\
\text { environment. (p. 96) }\end{array}$ & $\begin{array}{l}\text { Includes humans and } \\
\text { their environment and } \\
\text { data transmission through } \\
\text { physical position, } \\
\text { movement and visual } \\
\text { expression, speech pauses } \\
\text { and rates, and many other } \\
\text { non-verbal interactions. } \\
\text { (pp. } 104 \text { and 105). }\end{array}$ \\
\hline $\begin{array}{l}\text { Rapoport } \\
\text { on Geosite } \\
\text { Scale }\end{array}$ & $\begin{array}{l}\text { element in the } \\
\text { natural form that } \\
\text { does not change or } \\
\text { is maintained for } \\
\text { conservation } \\
\text { purposes, and area } \\
\text { icons can be in the } \\
\text { form of Mountains, } \\
\text { Valleys, Caves, } \\
\text { Rivers, natural } \\
\text { landscapes } \\
\end{array}$ & $\begin{array}{c}\text { element in the way of } \\
\text { accessibility, amenities, } \\
\text { supporting facilities in the } \\
\text { form of buildings, } \\
\text { environmental roads, and } \\
\text { environmental governance }\end{array}$ & $\begin{array}{l}\text { Non-permanent element } \\
\text { in a geosite are all } \\
\text { activities related to } \\
\text { activities that occur in } \\
\text { geoforest, tourism, } \\
\text { hawkers, and geosite } \\
\text { management activities }\end{array}$ \\
\hline
\end{tabular}

\section{Table 1: Rapoport model on Geosite}

Source: Author's Analysis (2018)

\section{Methodology}

This research's approach method was field survey, mapping, topographic interpretation, remote sensing, and tourism development assessment. The method used in this research is descriptive research because in this study it does not provide treatment and does not manipulate variables, but this research provides an overview or description of changes in land use and its relationship with tourism. Data were used for analysis came from field surveys, in-depth interviews, and previous research. Remote sensing data used aerial photographs on a scale of 1:35,000 and satellite images (Google Earth). Identification of space elements related to tourism development in this geosite was carried out through in-depth surveys and interviews. The database used are primary and secondary data. Data from this study were collected from the results of field surveys by observing the history of land use, plans, and functions of buildings. Further analysis is described in terms of the relationship between land use and tourist facilities or accommodation and plans. The analysis is also carried out to see the relationship between tourism and the development of spatial elements which include fixed elements, semi-fixed elements and non-fixed elements.

\section{Area of Study}

This research was conducted in the WatuPayung-Turunangeosite area. This area is a Biosite located in the Mount Sewugeopark, Gunungkidulgeoarea, Yogyakarta Province. WatuPayung Derivative Forest is a conservation forest at the western end of Panggang District, Gunungkidul Regency. WatuPayung occupies a land area of 17.40 hectares with an altitude of about 300 meters above sea level. 


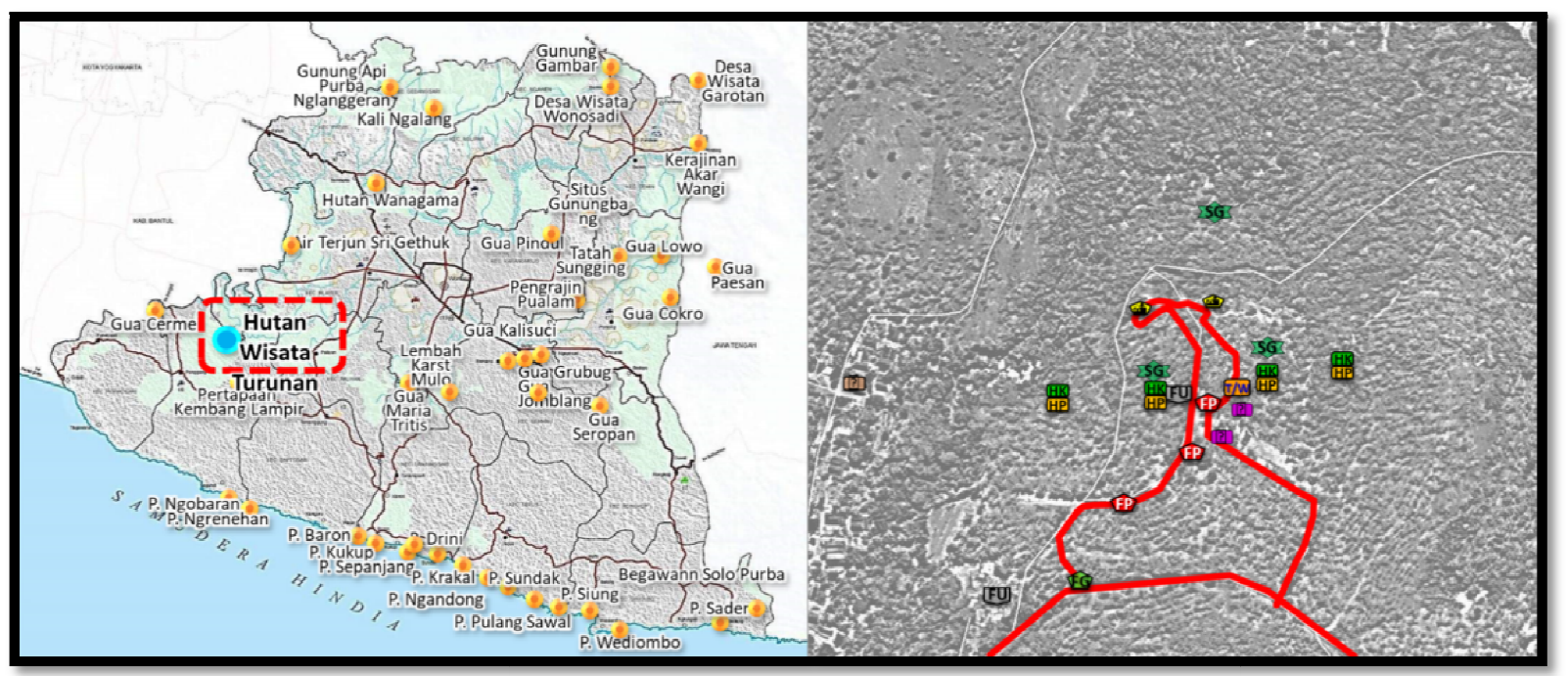

Figure 3: Map of Area of Study and Tourism Facility Distribution

Source: Gunungkidul Regencyand Observation,2017

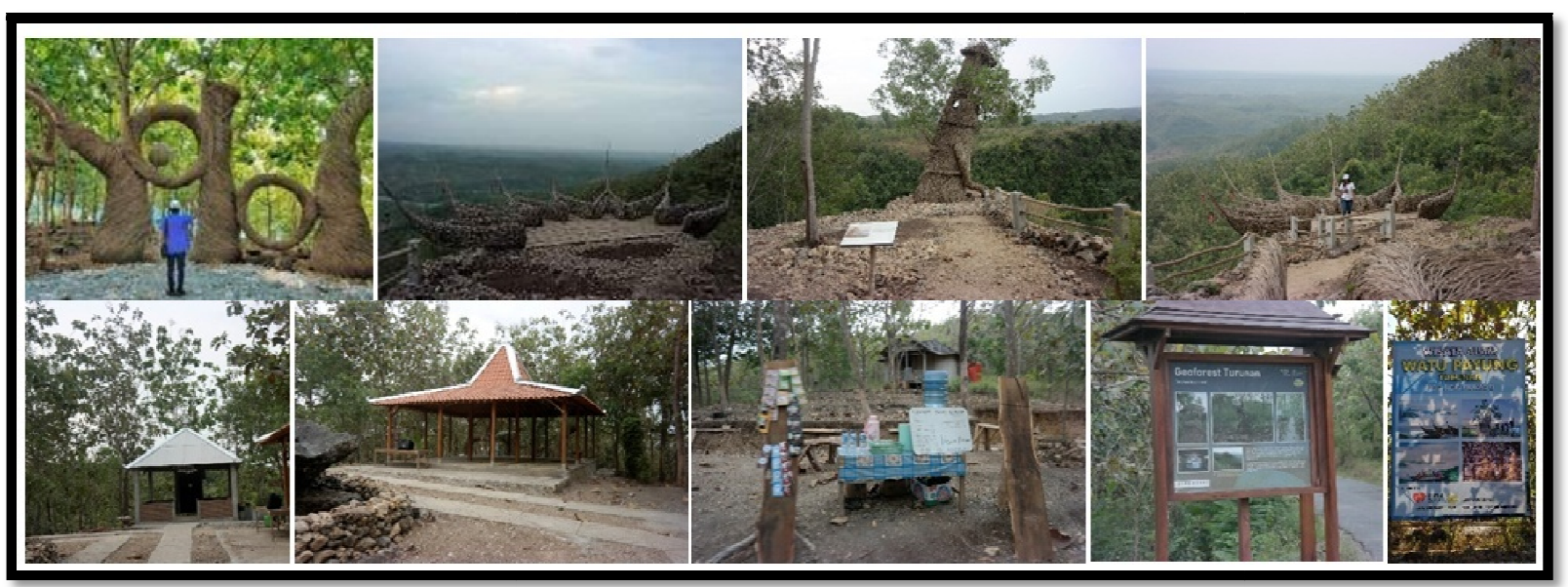

Figure 4: LandUse andTourism Facility Distribution

Source:GunungkidulRegencyandObservation,2017

\section{Result and Discussion}

\subsection{Watu Payung-Turunan Geoforest Tourism Development}

Gunungsewu Geopark is a geopark that stretches across three different areas, from Gunungkidul, Wonogiri, to Pacitan, with regional characters of hilly karst, limestone, caves, underground rivers, waterfalls, basin areas, and more. WatuPayung-TurunanGeoforest is a conservation forest in the far West Panggang District, Gunungkidul Regency. This forest has sufficient biodiversity and panoramic views of the limestone mountains, which are beautifully divided by the Oyo river. Another name of the WatuPayung forest is Turunan forest since it is located in Turunan village. WatuPayung occupies an area of 17.40 hectares located 300 meters above sea level. The name WatuPayung is taken from this location icon, a stone umbrella-shaped. The icon can be seen at the front entrance of the pendapa1WatuPayung. The name of WatuPayung refers to the stone's history, which served as a shelter for residents during the Dutch colonial period.

Geopark has the opportunity to be developed into destinations and tourist attractions with the geotourism approach. Besides, geopark can also be developed into a trading place and manufacturing of handicrafts (geo products) such as fossil molds and souvenirs that will create jobs and new economic growth. A national geopark is managed by the government. In the initial phase, WatuPayung-TurunanGeoforest is a teak production forest that also a semiconservation forest managed by the forestry ministry in cooperation with local society. There were no facilities developed during the forest conservation period. This area can be accessed because it is located on the edge of an arterial road between Panggangsub-district to Playen sub-district, Gunungkidul district. However, the quality of the access road is limited. During this period, people were given access to take advantage of the forest without damaging or changing the forest's status, such as use branches and harvest grass for their livestock.

In 2013, when WatuPayung-TurunanGeoforest was established as part of the Gunungsewugeopark, the community developed access to the area and built pendapa and parking lot to greet the new status. WatuPayungTurunanGeoforest is located in Turunan Hamlet, Girisuko Village, Gunungkidul Regency, about 21 kilometres or 40

${ }^{1}$ Pendapa is a building with traditional Javanese architecture, generally located in front of the main building complex used for various community interests. 
minutes of travel time from Yogyakarta. Hilly tour of GunungkidulWatuPayungTurunan Forest presents natural scenery such as the Opak River and it's overlay of trees. This geoforest is currently popular among tourists. In fact, WatuPayungTurunanGeoforest is a new tourist attraction that becomes viral on social media. The emergence of photo spots triggered high enthusiasm from the tourists to visit the geoforest. The view spot was built by the Indonesian Arts Institute students and later rapidly shared through social media. Social media has promoted geoforest nature's beauty and provokes people, both from the surrounding and outside the area to visit it.

UNESCO (2006) has developed criteria for assessing the readiness and suitability of an area to become a geopark, and WatuPayung-Derunangeoforest has met these requirements, as can be seen in the table below:

\begin{tabular}{|c|c|c|}
\hline $\begin{array}{c}\text { Variable \& } \\
\text { Dimensional }\end{array}$ & Indicator & Condition \\
\hline \multirow[t]{3}{*}{$\begin{array}{l}\text { 1. Size and } \\
\text { parameter - Physical }\end{array}$} & $\begin{array}{l}\text { Earth tourism areas must have limits and sufficient } \\
\text { space for economic development }\end{array}$ & $\checkmark$ \\
\hline & $\begin{array}{l}\text { The terrestrial tourism area must have sufficient } \\
\text { limits and space for local activities }\end{array}$ & $\checkmark$ \\
\hline & $\begin{array}{l}\text { Has a significant, rare geological heritage beautiful, } \\
\text { and scientific value }\end{array}$ & $\checkmark$ \\
\hline \multirow[t]{2}{*}{$\begin{array}{l}2 . \quad \text { Management } \\
\text { - Social }\end{array}$} & $\begin{array}{l}\text { - Has a management agency that acts bring } \\
\text { stakeholders together with public }\end{array}$ & $\checkmark$ \\
\hline & $\begin{array}{l}\text { Local government and community involvement, } \\
\text { central government support }\end{array}$ & $\checkmark$ \\
\hline $\begin{array}{l}3 . \quad \text { Economic } \\
\text { Development } \\
\text { Economy }\end{array}$ & $\begin{array}{l}\text { - Stimulates local economic activity with principles } \\
\text { of sustainable development and creating a local business }\end{array}$ & $\checkmark$ \\
\hline $\begin{array}{l}\text { 4. Education - } \\
\text { Educative }\end{array}$ & $\begin{array}{l}\text { Availability of supporting equipment for science } \\
\text { development }\end{array}$ & $\checkmark$ \\
\hline \multirow{2}{*}{$\begin{array}{l}5 . \quad \text { Conservation } \\
\text { and Protection - } \\
\text { Sustainable }\end{array}$} & $\begin{array}{l}\text { - Strengthening conservation development facilities } \\
\text { protected area }\end{array}$ & $\checkmark$ \\
\hline & $\begin{array}{l}\text { - The responsibility of the manager to ensure the } \\
\text { protection of geological heritage and implemented } \\
\text { according to local traditions and regulations }\end{array}$ & $\checkmark$ \\
\hline $\begin{array}{l}\text { 6. Global } \\
\text { Network Cooperation } \\
-\quad \text { Networking or } \\
\text { teamwork }\end{array}$ & $\begin{array}{lcc}\text { - } & \text { Exchange knowledge and expertise } & \text { with } \\
\text { destinations other terrestrial tours first developed } & \end{array}$ & $\checkmark$ \\
\hline
\end{tabular}

Table 2: Assessment of geopark indicators at WatuPayung-TurunanGeoforest Source: author's analysis (2018)

Based on these criteria, WatuPayung-TurunanGeoforest is declared as a geoforest. This improvement was followed by the significant enhancement number of visits, especially after 2017, after a group of artists named "PandaiRuang," led by WisnuAjitama, assisted by residents, put their artwork in the form of land-art made from Saliara plants (Lana Camara). Four artworks later became a photo spot that eventually became the central icon on GeoforestWatuPayung-Turunan. The land art's existence is an emerging tourism activity that provides opportunities for increasing the community's welfare. This initial stage of tourism is driven by its development and facilities and attractions addition in geosite.

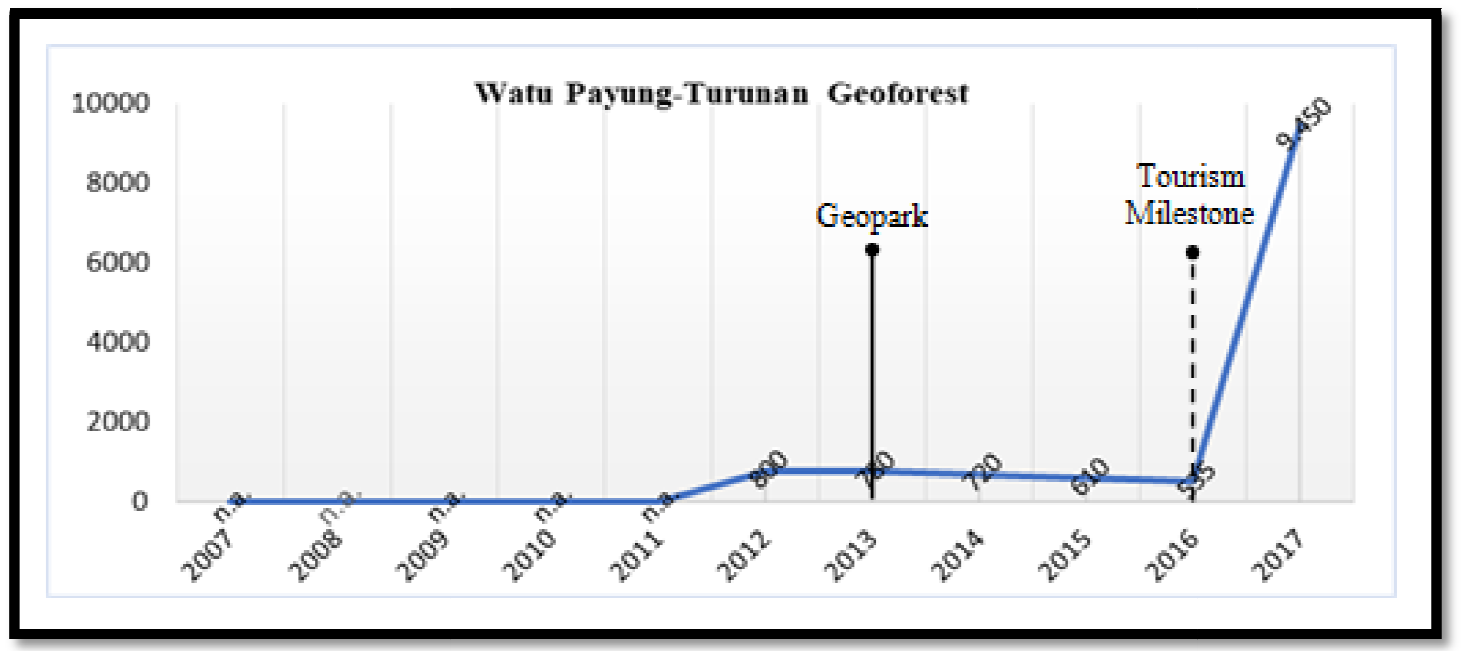

Figure 5: Graph of the Number of Visits to WatuPayung-TurunanGeoforest 


\section{Tourist Growth Rate on Watu Payung-Turunan Geoforest}

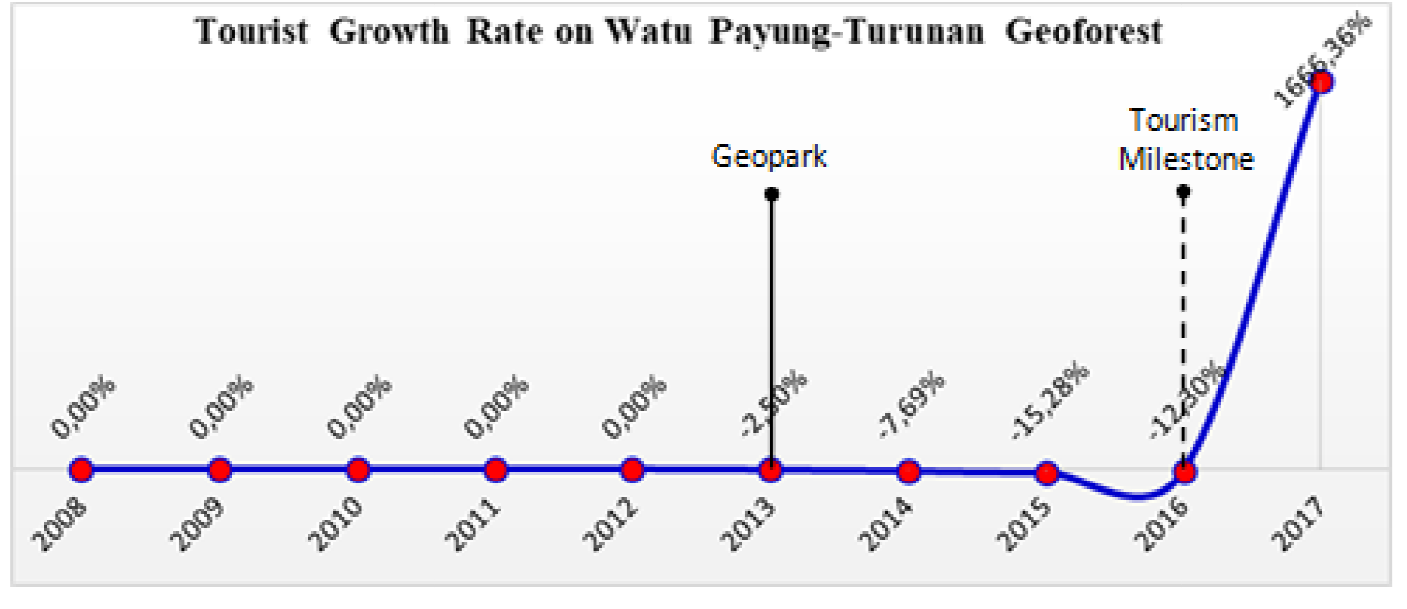

Figure 6: Graph of the growth rate of visits to WatuPayung-Turunan Geoforest

Data (Figure 5-6) shows an increase in the number of visits between 2016 to 2018 from 800 visits to 12,095 visits, or the equivalent of $1666.36 \%$. This increase occurred after the area was widely recognized as a tourism destination, not merely as a geopark. In detail, the development of WatuPayung-Derivative Geoforest as a tourist destination can be seen in the following table:

\begin{tabular}{|c|c|}
\hline Indicator & Result \\
\hline Location & $\begin{array}{l}\text { - WatuPayung-TurunanGeoforest, }(240-262 \mathrm{~m} \text { - above mean sea level), The } \\
\text { price of admission is affordable }<20 \text { thousand }\end{array}$ \\
\hline $\begin{array}{l}2 . \quad \text { Achieving } \\
\text { Process }\end{array}$ & $\begin{array}{l}\text { - } 10-15 \text { minutes from the parking area } \\
\text { - Does not require expertise }\end{array}$ \\
\hline $\begin{array}{l}3 . \quad \text { Initial } \\
\text { conditions } \\
\text { character }\end{array}$ and & $\begin{array}{l}\text { - Develops as a DTW starting in } 2017 \text {, in the form of tourist attraction } \\
\text { interests, specifically adventure forest conservation, agritourism }\end{array}$ \\
\hline $\begin{array}{l}4 . \quad \text { Access, } \\
\text { Distance \& time } \\
\text { (from Jogja) }\end{array}$ & $\begin{array}{l}\text { - A distance of } 30 \mathrm{Km}, 55-65 \text { minutes, condition of paved roads and } \\
\text { concrete cast. Could bus reachable. } \\
\text { - No public transportation is available; road signs are not clear. }\end{array}$ \\
\hline $\begin{array}{l}5 . \\
\text { Rate }\end{array}$ & $\begin{array}{l}\text { 9,450 } \\
\text { - Increased in 2017. Contributing } 0.27 \% \text { of the total } \\
\text { - Length of visit } 2.04 \text { hours, index repeater } 14 \%\end{array}$ \\
\hline $\begin{array}{l}\text { 6. Growth Rate } \\
\text { \& Tourism Space }\end{array}$ & $\begin{array}{l}\text { - Drastically increased in } 2018 \\
\text { - Tourism space is formed }\end{array}$ \\
\hline $\begin{array}{l}7 . \quad \text { Space } \\
\text { changes and } \\
\text { additions }\end{array}$ & $\begin{array}{l}\text { - Landscape } \\
\text { - Protection Forest and Production Forest } \\
\text { - Restroom, parking, worship facilities } \\
\text { - Roads \& Zoning } \\
\text { - Pendapa } \\
\text { - Electricity, lighting, clean water, telecommunications networks } \\
\text { - Tourism signs \& posts, Geosite information boards \& Regional signage } \\
\text { - Viewpoint } \\
\text { - Retribution Post }\end{array}$ \\
\hline $\begin{array}{l}\text { D. Development } \\
\text { of activities in the } \\
\text { area }\end{array}$ & $\begin{array}{l}\text { - Tourist Activities } \\
\text { - Trekking activities } \\
\text { - Food and drink shopping activities } \\
\text { - Street vendor } \\
\text { - grocery stalls, food stalls, and drinks } \\
\text { - artwork as a selfie photo location }\end{array}$ \\
\hline
\end{tabular}

Table 3: The Development of WatuPayung-TurunanGeoforest as a Tourism Destination Source: Author's Analysis (2018)

The attractiveness of WatuPayung-TurunanGeoforest that everyone can easily enjoy and the location not too far from Yogyakarta's city support this area's development as a tourism destination. Land ownership provides an opportunity for area managers to provide various facilities for tourists. From the table 3 above, it can be seen that the dominance of development comes from tourism requirements. Demands arise due to the development of tourism that can be fulfilled easily because of land availability. 


\subsection{Space Change}

Space changes that occur in WatuPayung-TurunanGeoforest began to occurred after the influx of tourism in the region. The determination of space elements in a geopark is intended to facilitate observation of the space change process that occurs within the geopark. By this grouping, the changes in space represented by the changes of spaceforming elements can be known. Even the factors that affected space changes in the geosite can be better identified. Land use observations are carried out to review changes in the area of space. Yeates and Garner (1980) model in Sajow, Rondonuwu, and Makainas (2016) was used to divide the land into settlements, industry, commercial, roads, public space, and vacant land. The gradation of space change at WatuPayung-TurunanGeoforest can be observed in the table below:

\begin{tabular}{|c|c|c|c|}
\hline \multicolumn{5}{|c|}{ Development of Space Elements } \\
\hline Before 2013 & $\mathbf{2 0 1 3 - \mathbf { 2 0 1 5 }}$ & $\mathbf{2 0 1 7}$ & $\mathbf{2 0 1 8}$ \\
\hline River Valley (V) & River Valley (V) & River Valley (V) & River Valley (V) \\
\hline Conservation Forest (V) & Conservation Forest (V) & Conservation Forest (V) & Conservation Forest (V) \\
\hline Production forest (C) & Production forest (C) & Production forest (C) & Production forest (C) \\
\hline & Geosite (C) & Geosite (C) & Geosite (C) \\
\hline & $\begin{array}{c}\text { Geosite signage \& } \\
\text { information (C) }\end{array}$ & $\begin{array}{c}\text { Geosite signage \& } \\
\text { information (C) }\end{array}$ & $\begin{array}{c}\text { Geosite signage \& } \\
\text { information (C) }\end{array}$ \\
\hline & & Geosite Management (C) & Geosite Management (C) \\
\hline & & Pendapa (C) & Pendapa (C) \\
\hline & & Viewing post (C) & Viewing post (C) \\
\hline & & Restroom (C) & Restroom (C) \\
\hline & & Mosque (C) & Mosque (C) \\
\hline & & Food stalls (C) & Food stalls (C) \\
\hline & & Selfie point (C) & Selfie point (C) \\
\hline
\end{tabular}

Table 4: Development of Space Elements at WatuPayung-TurunanGeoforest

* Settlements (S), Industry (I), Commercial (C), Roads (R), Public Space (P), and Vacant Land (V) Source: Author's Analysis (2018)

Land use in WatuPayung-TurunanGeoforest based on Yeates and Garner's (1980) model is dominated by public land in state-owned land used for tourism, commercial usage, and vacant land (table 4). The initial stage of land change is the change from production forest into geoforest. The geoforest status triggered the emergence of several public facilities, which later turned into tourism facilities. This change occurred spontaneously as a result of the arrival of tourists. Figure 7 provides an overview of the space changes that occur on this geoforest.

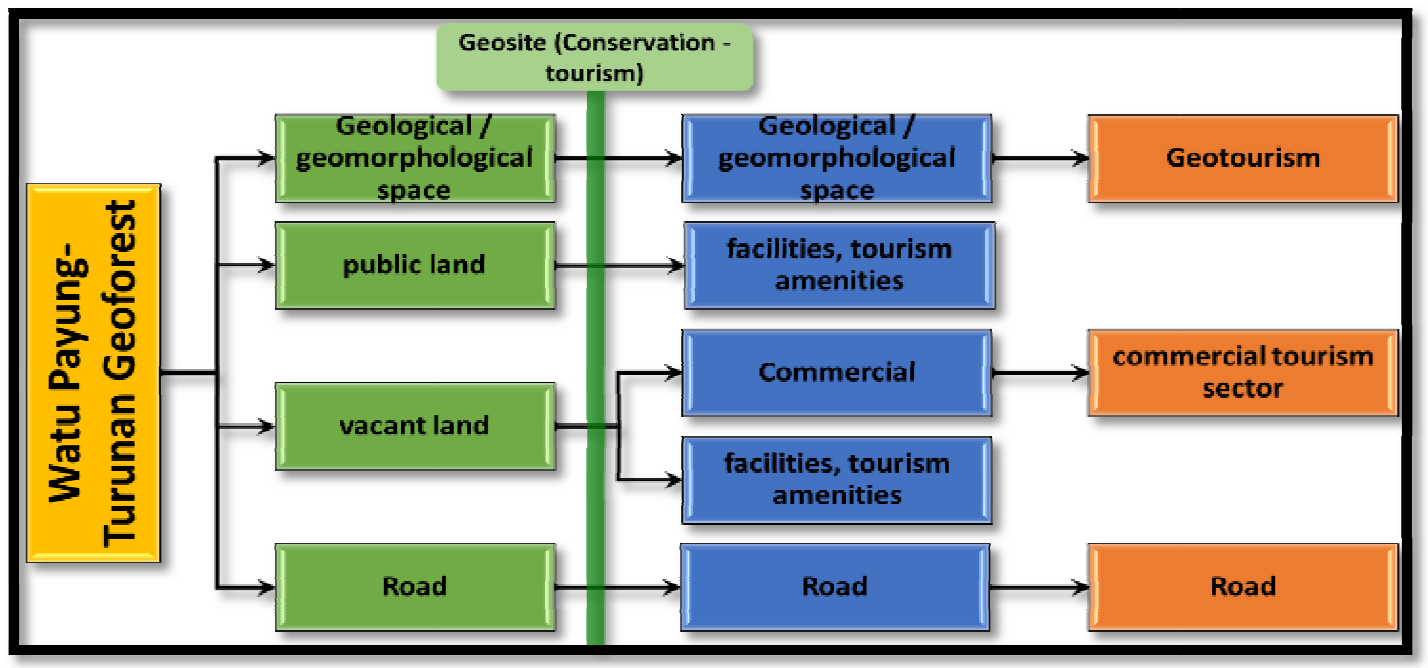

Figure 7: Land Use Component (An Adaptation of Yeates And Garner 1980) and Changes in WatuPayung-TurunanGeoforest

Land usage changes can be observed after 2013 following the launching of the geopark program, which is demanded some facilities' availability. It can be observed on the map that there is no significant land usage that differs before and after 2013 (determining the geopark). From 2013 to 2015 (figure 7), the facilities that developed were only the area marker boards and open space for the observation area. Both are only for the requirement as a geopark and do not intend to increase the visits. 


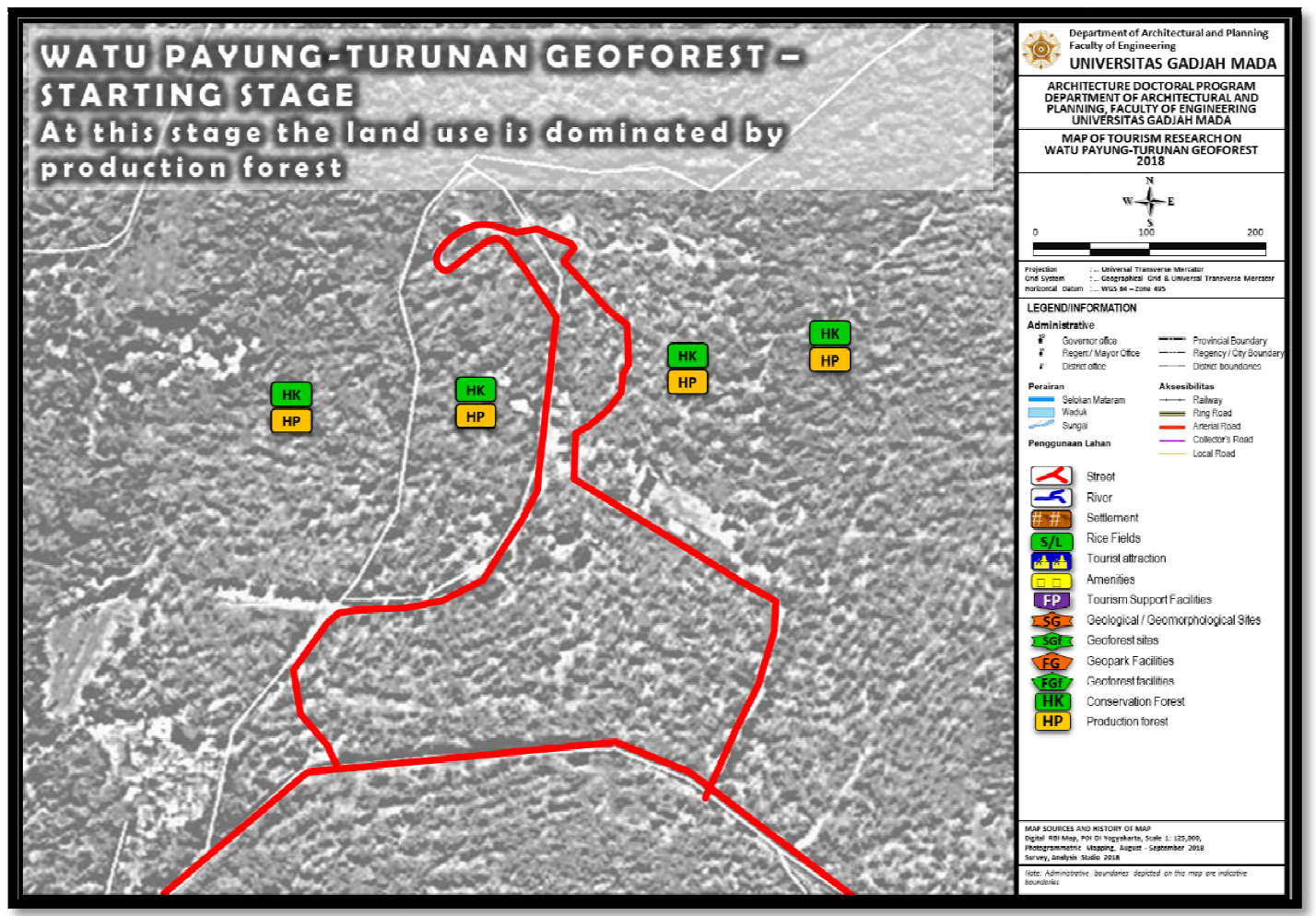

Figure 8:Map of WatuPayung-TurunanGeoforest Land Use Before Geoparkand Tourism Stages (Before 2013)

The 2013 to 2016 phase is a pure geoforest phase as part of the Gunungsewugeopark (figure 9). In this phase, land changes are immensely minor. The available land still retains its original function as a conservation forest. The minor change in space occurs because, at that stage, the number of tourist visits is still low, ranges from 500 to 800 visits per year. Visitors mostly come for the interests of scientific research. Mapping results show that there are only two points of change, which are the open space for geoforest interests and the geoforest signboards.

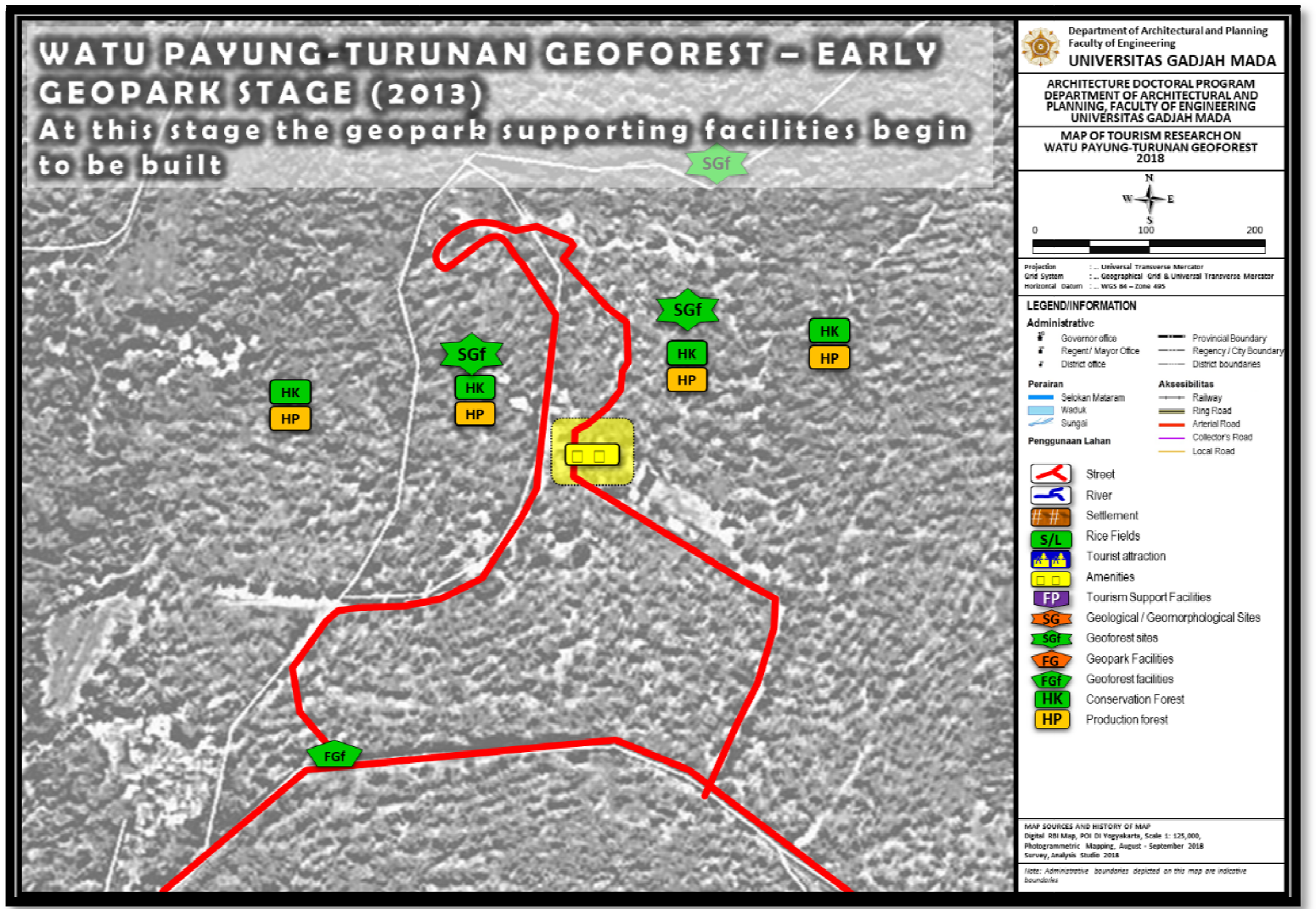

Figure9: Map of WatuPayung-TurunanGeoforest Land Use in the Early GeoparkStages (2013)

The development of tourism is more effective after 2017 (figure 10). The development of tourism has 
implications for the existing space changes in this area. These changes are in the form of landscaping improvements, adding pedestrian paths, structuring the flow of visits, providing restroom and prayer rooms, arranging traders, and retribution posts. The presence of the icon stimulates growth in the number of geoforest visitors. The increase in the number of tourist visits impacts the development of other new tourism support facilities. The demand of tourists for tourism supporting facilities has been well responded by the community. They build and develop tourism facilities to provide services that satisfy tourists.

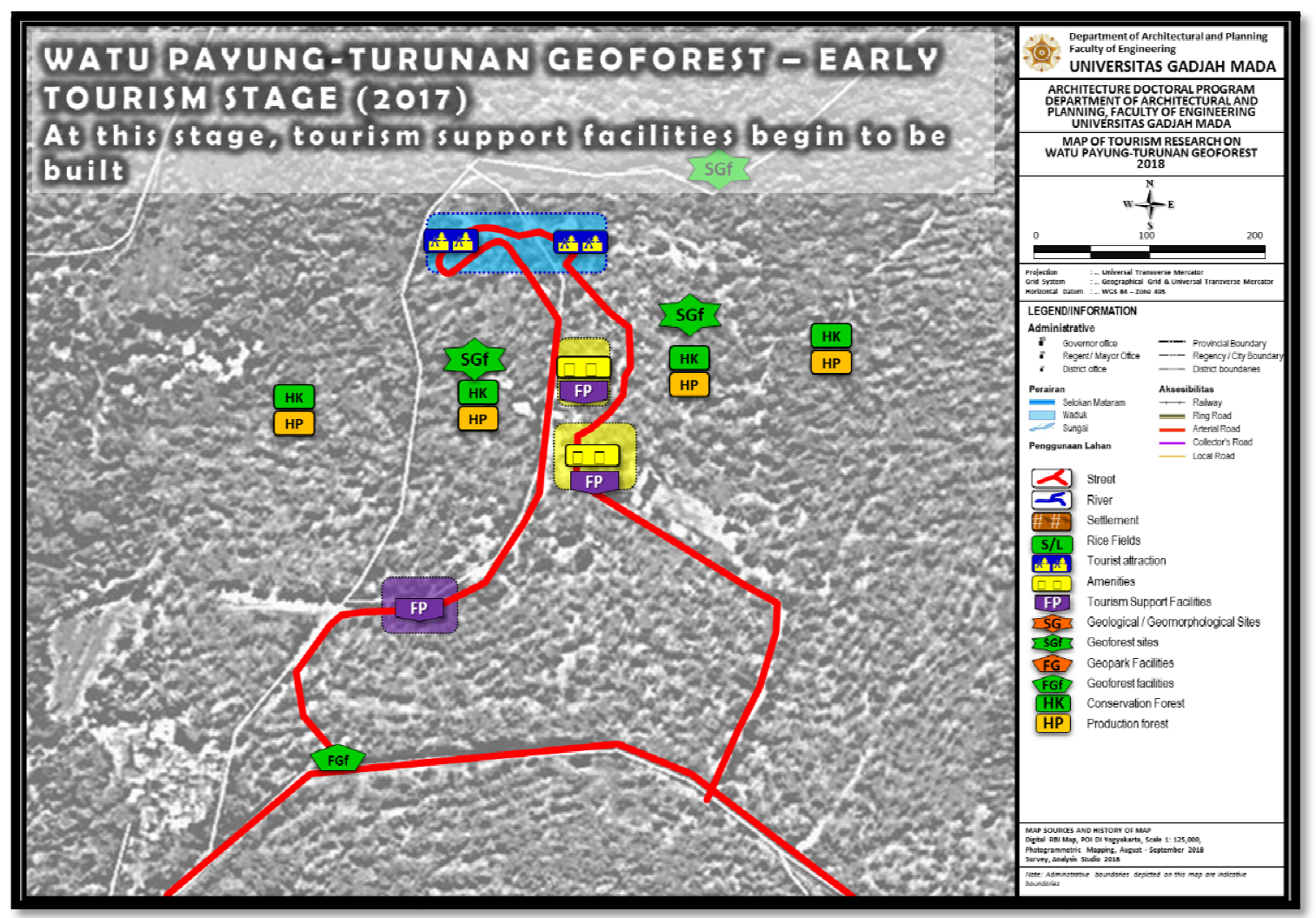

Figure10: Map of Watu Payung-TurunanGeoforest Land Use in the Early Tourism Stages (2017)

The increasing number of tourists triggers developments within and outside the core area. The development of accessibility and facilities includes inter-district crossroads, area entrances (local roads), pendapa, and parking (figure 11). Even though the needs of tourists are the trigger, developments are carried out to meet the needs of tourists and also for the benefit of the people that crossing this area. The development of space-related to tourists' needs when traveling in this area is carried out, such as food and beverage stalls, parking for tourist vehicles, rest areas, places of worship, and area arrangement.

In connection with the concept of space elements put forward by the Rapoport model, this phenomenon can also be seen in this geosite. Space-forming elements were observed in the analysis of land-use change from in-depth interviews. The aerial photography analysis results also show the development of the geosite following the changing patterns of the elements that make up space.

The harnessing of Geoforest core zones is limited without changing the primary function of Geoforest. The core zone of Geoforest has a role as a fixed element, while accessibility, facilities, and amenities play the role of a semi-fixed element. The semi-fixed element develops in the fixed element without changing the fixed element into a semi-fixed element. Non-fixed elements develop in both fixed and semi-fixed elements in tourist activities and community empowerment activities in tourism services. 


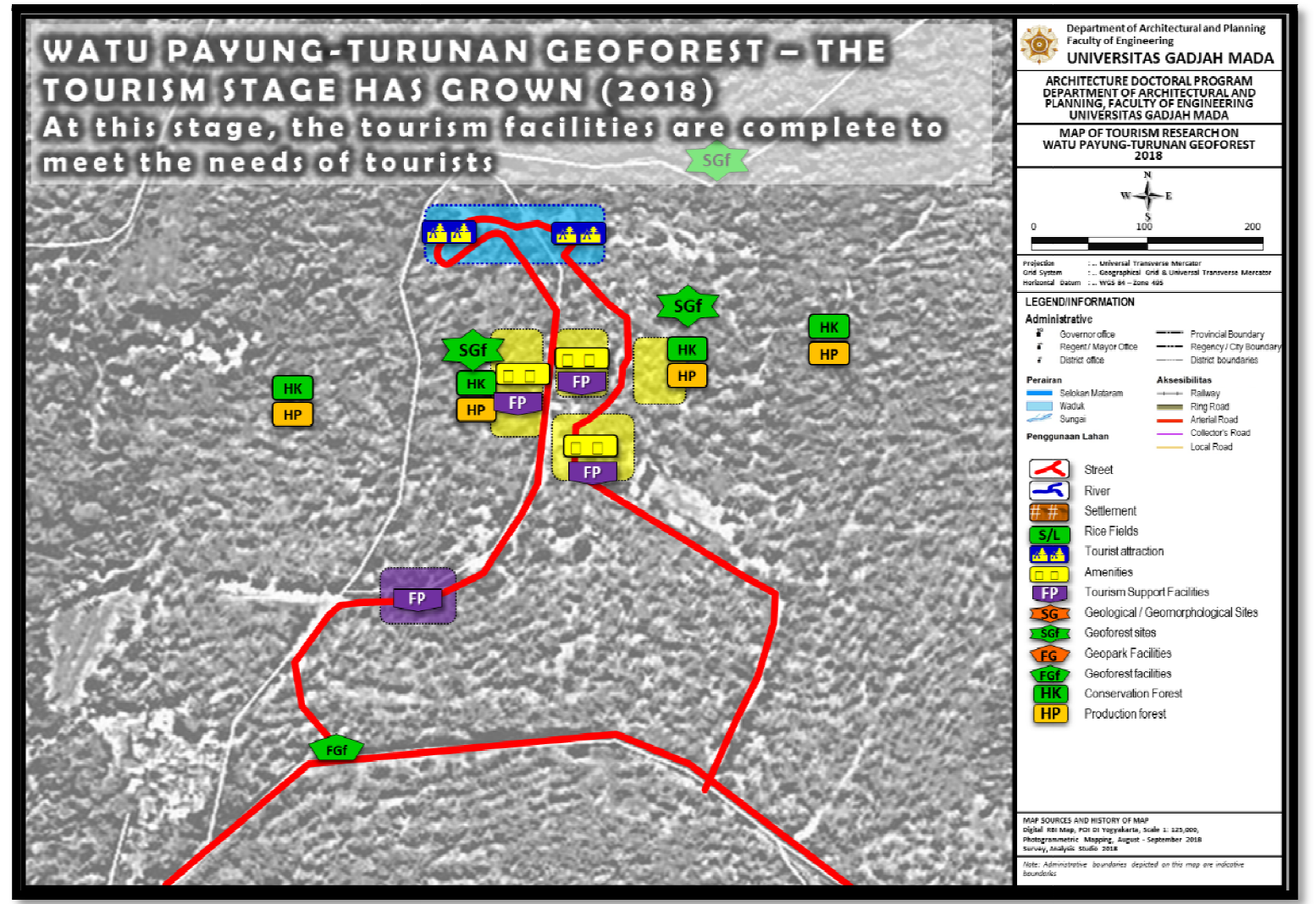

Figure11: Map of Watu Payung-Turunan Geoforest Land Use in the Tourism Stage Has Grown (2018)

The development of tourism activities strongly influences the development and change of space in WatuPayungTurunanGeoforest. The uniqueness of the facilities is a crucial factor in the development of tourism, which then has implications for changes in the land function. The development of space was dominated by requirements to meet the needs of tourism management. The space changes that occur show the impact of activities and atmosphere related to tourism. Changes in the geosite into tourism-related spaces are often referred to as tourism spaces. Warszyńska and Jackowski (1979), in Więckowski (2014), state that the entire geographical and socio-economic area where the phenomenon of tourism occurs is referred to as tourism space. At the same time, Liszewski and Bachvarov (1998) explain that tourism space is a whole idea that includes all forms of actualization and tourism expression that occurs in a particular region (Więckowski 2014). The development of tourism space throughout WatuPayung-TurunanGeoforest is marked by the emergence of various tourist activities and visits that have an impact on:

- Linkages between tourists, the public, the private sector, and the government (tourism actors)

- The integration of tourism in the daily community life

- Development of facilities, tourism business

- Increasing awareness of tourism in the community, government, and private sector

In line with what was expressed by Więckowski (2014) and Ateljevic and Doorne (2008), Gordon and Goodall (2000), Hultman and Hall (2012) in Prince (2017), these four things since 2017 began to be seen at WatuPayungTurunan Geoforest. The map shows the gradations of change caused by the emergence of tourism activities from 2017 to 2019. The relationship between tourism and space can be seen from the indicators that shape the tourism space in semifixed elements due to tourists' demands and requirements of tourism development. The trigger for this space change can be observed in the following table: 


\begin{tabular}{|c|c|c|c|c|}
\hline Initial Land-use & Land-use Change & $\begin{array}{c}\text { Type of } \\
\text { Element }\end{array}$ & Triggers of Change & Year \\
\hline 1. Conservation Forest & Conservation Forest & Fixed & $\begin{array}{l}\text { Government, the needs } \\
\text { of conservation }\end{array}$ & before 2013 \\
\hline 2. Production forest & Land environment road & Semi-fixed & Citizens' needs & before 2013 \\
\hline 3. Production forest & Open field & Semi-fixed & Citizens' needs & 2013 \\
\hline 4. Production forest & Geopark facilities & Semi-fixed & $\begin{array}{l}\text { GunungsewuGeopark } \\
\text { development needs }\end{array}$ & 2013 \\
\hline 5. Open field, footpath & $\begin{array}{l}\text { Macadam road, } \\
\text { landscaping }\end{array}$ & Semi-fixed & $\begin{array}{c}\text { GunungsewuGeopark } \\
\text { development needs }\end{array}$ & 2013 \\
\hline $\begin{array}{l}\text { 6. Production forest, open } \\
\text { field }\end{array}$ & landscaping & Semi-fixed & $\begin{array}{c}\text { GunungsewuGeopark } \\
\text { development needs }\end{array}$ & 2013-2016 \\
\hline 7. Production forest & Art showroom installation & Semi-fixed & $\begin{array}{l}\text { - The needs of } \\
\text { local artists } \\
\text { - } \quad \text { Tourism needs }\end{array}$ & 2017 \\
\hline 8. Open field & Pendapa & Semi-fixed & Tourism needs & 2017 \\
\hline $\begin{array}{l}\text { 9. Road macadam } \\
\text { environment }\end{array}$ & $\begin{array}{l}\text { Road concrete cast } \\
\text { environment }\end{array}$ & Semi-fixed & Tourism needs & 2017 \\
\hline Open field & Parking area & Semi-fixed & Tourism needs & 2017 \\
\hline 11. Open field & Food and drink area & Semi-fixed & Tourism needs & 2017 \\
\hline 12. $\quad$ Production forest & $\begin{array}{l}\text { Road concrete cast } \\
\text { environment }\end{array}$ & Semi-fixed & Tourism needs & 2018 \\
\hline Open field & Photo Spot & Non-fixed & Tourism needs & 2018 \\
\hline Open field & Viewing post & Semi-fixed & Tourism needs & 2018 \\
\hline Open field & Restroom & Semi-fixed & Tourism needs & 2018 \\
\hline Open field & Mosque & Semi-fixed & Tourism needs & 2018 \\
\hline
\end{tabular}

Table 5: Table of Space Changeans and Its Triggers

Source: Author's Analysis (2018)

The table above shows the space changes caused by residents' needs only lasted until 2013. Space changes in the 2013-2016 period were influenced by the need for community and geopark development in this area. In 2017, tourism's inclusion changed the motivation for space changes that initially met citizens and geopark's needs and later became to meet tourism development requirements. The vacant land is transformed into various semi-fixed elements, also became the location of different activities related to the non-permanent element, namely tourism-related activities.

Tourists who come to the geoforest are mostly tourists with photography tourism motivation. Photography tourism develops in the form of landscape photography or self-photography, or "selfie." This photography tourism activity demands improvements to the scenery, making photo points, providing food and drinks, and various other facilities to facilitate tourism activities. This demand is also related to the behavior of tourists using social media to share images. Unique and iconic landscapes will attract many tourist visits. The demand for tourists will increase along with the increasing number of visitors to this geoforest. Responding to tourist requests, the WatuPayung-TurunanGeoforest manager carried out a plan in the context of landscaping. The planning is focused on the construction of tourism facilities and public facilities related to tourism while still paying attention to environmental preservation rules. 


\begin{tabular}{|c|c|c|c|}
\hline Year & $\begin{array}{l}\text { Number of } \\
\text { Tourists }\end{array}$ & Non-fixed Element Development & Semi-fixed Element Development \\
\hline $\begin{array}{l}\text { Before } \\
2012\end{array}$ & $\mathbf{n} / \mathbf{a}$ & cultivator activity & $\begin{array}{ll}\checkmark & \text { Conservation forest } \rightarrow \text { Production } \\
\text { forest } & \end{array}$ \\
\hline 2012 & 800 & $\begin{array}{l}\text { local activities } \\
\text { research activities }\end{array}$ & $\begin{array}{ll}\checkmark & \text { Conservation forest } \rightarrow \text { Production } \\
\text { forest } & \end{array}$ \\
\hline 2013 & 780 & $\begin{array}{l}\text { local activities } \\
\text { research activities }\end{array}$ & $\checkmark \quad$ Production forest $\rightarrow$ Geoforest \\
\hline 2014 & 720 & $\begin{array}{l}\text { local activities } \\
\text { research activities }\end{array}$ & Production forest $\rightarrow$ Geoforest \\
\hline 2015 & 610 & $\begin{array}{l}\text { local activities } \\
\text { research activities } \\
\text { Geopark Management activities }\end{array}$ & Production forest $\rightarrow$ Geoforest \\
\hline 2016 & 535 & $\begin{array}{l}\text { local activities } \\
\text { research activities } \\
\text { Geopark Management activities }\end{array}$ & Production forest $\rightarrow$ Geoforest \\
\hline 2017 & 9.450 & $\begin{array}{ll}\checkmark & \text { Geopark Management activities } \\
\checkmark & \text { research \& } \quad \\
\text { activities } \\
\checkmark & \text { art activity } \\
\checkmark & \text { tourist activities } \\
\checkmark & \text { traditional trading activities }\end{array}$ & $\begin{array}{ll}\checkmark & \text { Production forest } \rightarrow \text { Geoforest } \\
\checkmark & \text { Production } \\
\rightarrow \text { FasilitasGeoforest } \\
\checkmark & \text { Production forest } \rightarrow \text { landscaping } \\
\checkmark & \text { Production forest } \rightarrow \text { Pendapa } \\
\checkmark & \text { Art showroom installation } \\
\checkmark & \text { Road concrete cast environment } \\
\checkmark & \text { Parking area } \\
\checkmark & \text { Food and drink selling area }\end{array}$ \\
\hline 2018 & 16.760 & $\begin{array}{ll}\checkmark & \text { Geopark Management activities } \\
\checkmark & \text { research \& } \quad \\
\text { activities } \\
\checkmark & \text { art activity } \\
\checkmark & \text { tourist activities } \\
\checkmark & \text { traditional trading activities }\end{array}$ & $\begin{array}{ll}\checkmark & \text { Road concrete cast environment } \\
\checkmark & \text { entry ticket post } \\
\checkmark & \text { Photo Spot } \\
\checkmark & \text { Viewing post } \\
\checkmark & \text { Restroom, restroom repairs } \\
\checkmark & \text { Mosque } \\
\checkmark & \text { landscaping improvement } \\
\checkmark & \text { repair and extension of local roads }\end{array}$ \\
\hline
\end{tabular}

Table 6: Relationship between the Number of Visits and Additional Facilities Source: Author's Analysis (2018)

The analysis results in table 6 show that an increase in visits to a place will lead to various activities that originate from interactions between visitors, hosts, and the environment. The interaction of tourists with the visited areas encourages space change with the formation of new semi-fixed elements. Semi-fixed elements include tourism supporting facilities in the parking area, food, and drink stalls, entry ticket posts, photo spots, viewing posts, restrooms, prayer rooms, and extension of regional roads. For more details, the grouping of space elements in WatuPayungTurunanGeoforest are presented as follows:

\begin{tabular}{|c|c|c|}
\hline Fixed Element & Semi-fixed Element & Non-fixed Element \\
\hline $\begin{array}{ll} & \text { Landscape } \\
\text { - } & \text { Protection } \\
\text { Forest } \\
\text { Production } \\
\text { Forest }\end{array}$ & $\begin{array}{ll}\text { - } & \text { Restroom, parking, worship facilities } \\
\text { - } & \text { Roads \& Zoning } \\
\text { - } & \text { Pendapa } \\
\text { - } & \text { Electricity, lighting, clean water, } \\
& \text { telecommunications } \\
\text { - } & \text { Tourism signs \& posts, Geosite } \\
& \text { information boards \& Regional } \\
& \text { signage } \\
\text { - } & \text { Substation of view, } \\
\text { - } & \text { Retribution post }\end{array}$ & $\begin{array}{ll}\text { - } & \text { Tourist Activities } \\
\text { - } & \text { Trekking activities } \\
\text { - } & \text { Food and drink shopping } \\
\text { activities } \\
\text { - } \\
\text { - } \begin{array}{l}\text { groet vendor } \\
\text { and drinks } \\
\text { - } \\
\text { loctwork ation a selfie photo }\end{array}\end{array}$ \\
\hline
\end{tabular}

Table 7: Development Of Space Element in WatuPayung-TurunanGeoforest Source: Author's Analysis (2018)

The Rapoport model is used to classify spaces within geoforest based on the development of these spaces. The space development shows the dominance of the semi-fixed elements that occur on this geoforest. The semi-fixed element's development is the impact of the progress from various activities in WatuPayung-TurunanGeoforest. Tourismrelated activities taking place are included as a non-fixed element in Rapoport's model. 


\section{Conclusion}

In the development of a geopark, the various elements of the region's uniqueness are developed for three main interests: conservation of earth heritage, community development, and economic growth. To accommodate these three interests, WatuPayung-Turunan Geoforest uses a geological and morphological uniqueness-based tourism approach implemented in the Opak watershed, which divides the limestone formations in Gunungsewu. This development requires a new space known as a tourism space to meet the growing tourism needs in WatuPayung-Turunan Geoforest.

The space changes in WatuPayung-Turunan Geoforest can be observed through changes in the existing space elements, especially in semi-fixed elements. Changes in space elements create synergy between those three elements (fixed, semifixed, and non-fixed) and ultimately stimulating the formation of the tourism space. The most changing and the determinant of the structure of tourism space is the semi-fixed element. The dynamics of non-fixed elements in the form of tourism activities and other related activities significantly influence the development of semi-fixed elements on geoforest.

Understanding the space changes and the elements involved in these changes while knowing the causative factors is necessary for area managers. Managers' understanding of space elements' dynamics in the area will improve the quality of tourism planning and development in a geopark such as in GeoforestWatuPayung-Turunan. Management will maintain sustainability, conservation, economic growth, and community empowerment in a geoforest through good tourism planning and development. Apart from the manager, developing a geoforest also requires a policy from stakeholders in regulating geoforest management and providing better direction for development plans.

\section{Acknowledgment}

This research is a part of PhD thesis research, in accordance, we would like to appreciate The Indonesian Ministry of Research, Technology and Higher Education and Indonesian Endowment Fund for Education for the awarded of BUDI-DN Scholarship. We also would like to appreciate The Doctoral Program of Architecture, UniversitasGadjahMada, for all the assistance that makes this research conductible.

\section{References}

i. Amelia, DeonaFhenta. 2016. "Upaya Pemerintah Indonesia Menjadikan Kawasan Gunung SewuSebagai Unesco Global Geopark Network (GGN) Tahun 2013-2015. [The Indonesian Government's Efforts to Make Mount Sewu the Unesco Global Geopark Network (GGN) 2013-2015]." Jurnal Online Mahasiswa FakultasI lmuSosialdan Ilmu Politik Universitas Riau [Online Journal of Students of the Faculty of Social and Political Sciences, Riau University] 3(2): 1-14. http://jom.unri.ac.id/index.php/JOMFSIP/article/view/9377.

ii. Ateljevic, Irena, and Stephen Doorne. 2008. "Cultural Circuits of Tourism: Commodities, Place and Re-consumption.” In A Companion to Tourism, , 291-302. https://doi.org/10.1002/9780470752272.ch23.

iii. Cooper, Chris et al. 2005. Tourism: Principles and Practice. Pearson Education. https://books.google.co.id/books?id=OWonlWCgp34C.

iv. Darsiharjo, Upi Supriatna, and Ilham Mochammad Saputra. 2016. "Pengembangan Geopark CiletuhBerbasis Partisipasi Masyarakat Sebagai Kawasan Geowisata Di KabupatenSukabumi. [Development of Ciletuh Geopark Based on Community Participation as a Geotourism Area in Sukabumi Regency]." JurnalManajemen Resort dan Leisure [Journal of Resort and Leisure Management] 13(1): 55-66. https://doi.org/10.17509/jurel.v13i1.2036.

v. Davidson, R, and R Maitland. 1997. Tourism Destinations. Hodder \& Stoughton. https://books.google.co.id/books?id=mxFmQgAACAAJ.

vi. GeoparkGunungsewu Management. 2013. GeoparkGunungSewu, Jawa - DokumenUsulan MenjadiGeopark Nasional Dan Keanggotaan PadaJaringan Geopark Nasional Indonesia.

vii. Goeldner, Charles R., and J. R. Brent Ritchie. 2009. Tourism : Principles, Practices, Philosophies. Eleventh E. New York: Wiley. https://www.entornoturistico.com/wp-content/uploads/2018/04/Tourism-Principles-PracticesPhilosophies.pdf.

viii. Gunn, Clare A. 1994. Tourism Planning: Basics, Concepts, Cases, Third Edition. 3rd ed. Suite 200, Washington, D.C.: Taylor \& Francis, 1101 Vermont Avenue, N.W. https://doi.org/10.1177\%2F004728759403200371.

ix. Gunn, Clare A, and Terry R Larsen. 1988. Tourism Potential-Aided by Computer Cartography. Aix-en-Provence, France: Centres des Hautes Etudes Touristiques.

x. Hall, Colin Michael. 2000. Tourism Planning: Policies, Processes and Relationship 1. UK: Pearson Education. Ltd. https://books.google.co.id/books?id=p_C7QgAACAAJ.

xi. Haryanti, Dini Tri. 2008. "KajianPolaPemanfaatanRuang Terbuka PublikKawasanBundaranSimpang Lima Semarang. [Study of Public Open Space Utilization Patterns in the Simpang Lima Semarang Roundabout]." Universitas Diponegoro [Diponegoro University]. https://core.ac.uk/download/pdf/11716848.pdf.

xii. Keever, Patrick J. Mc, and Nickolas Zouros. 2005. “Geoparks : Celebrating Earth Heritage, Sustaining.” Episodes 28(December):

274-78.

https://www.researchgate.net/publication/258100065_Geoparks_Celebrating_Earth_heritage_sustaining_local_ communities.

xiii. Kikuchi, Toshio et al. 2011. "An Overview: Special Issue on 'Geoparks and Regional Development.”' Journal of Geography (ChigakuZasshi) 120(5): 725-28.

xiv. Komoo, Ibrahim. 2016. "Model for Environmental Sustainability: A Case of Langkawi UNESCO Global Geopark." In Synthesis Workshop of the Project STAR \& SHARP |, http://mucp-mfit.org/wp-content/uploads/4-Model-forEnvironmental-Sustain-Langkawi-Geopark-MALAYSIA-IBK.pdf. 
xv. Nadjmi, Nurul, WienduNuryanti, Budi Prayitno, and NindyoSoewarno. 2016. "PengembanganDestinasiPariwisata Di KepulauanSelayar Sulawesi Selatan. [Development of Tourism Destinations in the Selayar Islands, South Sulawesi]." UniversitasHasanuddin Makassar [Hasanuddin University Makassar]. http://eng.unhas.ac.id/arsitektur/files/587f0e845f42c.pdf.

xvi. Newsome, David, and Ross K Dowling. 2006. Geotourism, Sustainability, Impacts, and Management. eds. Ross K. Dowling and David Newsome. Burlington: Elsevier Butterworth-Heinemann. https://www.sciencedirect.com/book/9780750662154/geotourism\#book-info.

xvii. Nuryanti, Wiendu. 1996. "Heritage And Postmodern Tourism." Annals of Tourism Research 23(2): 249-60. https://doi.org/10.1016/0160-7383(95)00062-3.

xviii. Pforr, Christof, and Andreas Megerle. 2006. "Geotourism: A Perspective from Southwest Germany." In Geotourism, Elsevier Butterworth-Heinemann, Oxford, 118-39. https://doi.org/10.1016/B978-0-7506-62154.50015-4.

xix. Prince, Solène. 2017. "Imagining Tourist Spaces as Living Spaces - Towards a Relational Approach to Alternatives and Morals in Tourism." Sweden University. https://www.researchgate.net/publication/319127744_IMAGINING_TOURIST_SPACES_AS_LIVING_SPACES_To wards_a_Relational_Approach_to_Alternatives_and_Morals_in_Tourism.

xx. Putri, ShafiraMediana. 2019. "ShafiraMedianaPutri." Responsive 2(2): 33-39.

xxi. Rahmi, DwitaHadi, H A Sudibyakto, H Sutikno, and Laretna T Adishakti. 2012. "PusakaSaujana Borobudur: Perubahan Dan Kontinuitasnya. [Borobudur Cultural Landscape: Change and Continuity]." JurnalManusiadanLingkungan [Journal of Humans and the Environment] 19(1): 85-94. https://doi.org/10.22146/jml.18456.

xxii. Rapoport, Amos. 1997. Human Aspects of Urban Form: Towards a Man-Environment Approach to Urban Form and Design. New York: Pergamon Press.

xxiii. - - - 2005. Culture, Architecture and Design. Chicago Illinois: Locke Scientific.

xxiv. Rapoport, Amos, Irwin Altman, and Joachim F. Wohlwill. 1980. Human Behavior, Environment and Culture. New York: Plenum Press.

xxv. Robinson, Angus M. 2015. “Geotourism and Geoparks A Tourism Development Opportunity for Australia.” : 1-5. http://www.leisuresolutions.com.au/index.php/geotourism-industry-groups/.

xxvi. Soedarso, MuchammadNurif, and Windiani. 2014. "Potensi Dan

KendalaPengembanganPariwisataBerbasisKekayaanAlamDenganPendekatan Marketing Places

(StudiKasusPengembanganPariwisata Di KabupatenBojonegoro). [Potential and Constraints to Tourism Development Based on Natural Resources Using Marketi." JurnalSosialHumaniora [Journal of Social Humanities] $7(2): 136-49$.

xxvii. http://iptek.its.ac.id/index.php/jsh/article/view/582.

xxviii. Soeroso, YusdiantoHaryo. 2017. "StudiPengembanganDestinasiPariwisata Urban Di Jakarta (StudiKasus: Kawasan Kota Tua). [Urban Tourism Destination Development Study in Jakarta (Case Study: Kota Tua Area)].” UniversitasTarumanegara [Tarumanagara University]. https://issuu.com/dedesilka/docs/proposal_tesis_yusdianto_hs.

xxix. The Editors of Encyclopedia Britannica. 2017. "Space, Physics and Metaphysics." https://www.britannica.com/science/space-physics-and-metaphysics.

xxx. UNESCO. 2004. "Guidelines and Criteria for National Geoparks Seeking UNESCO's Assistance to Join the Global Geoparks Network (GGN).

xxxi. Więckowski, Marek. 2014. “Tourism Space: An Attempt at a Fresh Look." Tourism 24(1): 17-24. https://doi.org/10.2478/tour-2014-0002.

xxxii. Yeates, Maurice, and Barry J Garner. 1980. The North American City. Third Edit. San Francisco: Harper \& Row.

xxxiii. Yuliawati, Ayu Krishna, Krishna NurPribadi, and Mohamad SapariDwiHadian. 2016. "Geotourism Resources as Part of Sustainable Development in Geopark Indonesia." Atlantis Press 15: 962-65.

xxxiv. Zakaria, Faris, and DewiSuprihardjo. 2014. “KonsepPengembanganKawasanDesaWisata Di DesaBandunganKecamatanPakongKabupatenPamekasan.” JURNAL TEKNIK POMITS 3(2). http://dx.doi.org/10.12962/j23373539.v3i2.7292. 